\title{
PLANT ADAPTOGENS IN SPECIALIZED FOOD PRODUCTS AS A FACTOR OF HOMEOSTATIC REGULATION INVOLVING MICROBIOTA
}

\author{
I.Yu.Potoroko', irina_potoroko@mail.ru, ORCID: 0000-0002-3059-8061, \\ M.A. Berebin', berebinma@susu.ru, ORCID: 0000-0001-7195-8142, \\ I.V. Kalinina1, kalininaiv@susu.ru, ORCID: 0000-0002-6246-9870, \\ D.G. Ivanova ${ }^{2}$,dg_ivanova@yahoo.com, ORCID: 0000-0002-8336-2925, \\ Y. Kiselova-Kaneva ${ }^{2}$, ykisselova@abv.bg, ORCID: 0000-0001-9692-6227 \\ ${ }^{1}$ South Ural State University, Chelyabinsk, Russian Federation, \\ ${ }^{2}$ Medical University, Varna, Bulgaria
}

\begin{abstract}
The aim of this study is to develop an adaptogenic drink based on the polyphenol complex of antioxidant activity optimized in terms of bioavailability. Materials and Methods. The study was performed on the base of the polyphenol complex of antioxidant activity made of taxifolin (Larix gmelinii extract with no less than $97.0 \%$ of taxifolin) and plant extracts (Lonicera caerulea L., Beta vulgaris L. ssp.vulgaris) obtained in the research laboratory of the department of Food and Biotechnologies in the South Ural State University. To increase solubility and bioavailability of taxifolin we used 20-minute $630 \mathrm{~W}$ ultrasonic impact, providing taxifolin nanostructuring. The plant extract consists of reconstituted extracts from Beta vulgaris L. ssp.vulgaris and Lonicera caerulea $L$. in a 3:1 ratio with $0.1 \%$ of taxifolin and the amount of dry substance of no less than $15 \%$. Taxifolin content in a final product is no less than $0.02 \%$. Results. It was established that taxifolin water solution is quite sensitive to ultrasonic cavitation. The morphological structure of taxifolin particles, treated with ultrasound, was close to a spherical shape. Particles were characterized by amorphous structure, which is positive for solubility and bioavailability properties. Antioxidant activity is $1.74-1.98$ times higher than in the solutions obtained using a mechanical approach. This indicates the increased physiological value of solutions. The drink obtained on the base of beet and honeysuckle extracts with $0.1 \%$ taxifolin had the total content of betanin and betaxanthine equaled $54 \pm 2 \mathrm{mg} / 100 \mathrm{~g}$ and the total content of phenol substances of $194 \pm 4 \mathrm{mg}$ in terms of gallic acid. The consumption of a taxifolin plant extract-based drink results in the decrease of Streptococcus to significantly lower values. There is a shift in $\mathrm{pH}$ values in a range from 6.5 to 7.5 in comparison with the initial $\mathrm{pH}$ values of $5.5 \div 6.0$ units. Conclusion. The combination of secondary metabolites (polyphenols) in the form of Lonicera caerulea L. and Beta vulgaris L. ssp.vulgaris plant extracts with taxifolin is a very promising one for the technology of adaptogenic drinks to improve homeostatic mechanisms involving microbiota at the stage of oral intake.
\end{abstract}

Keywords: adaptogens, microbiota, specialized nutrition, antioxidant activity, bioavailability.

\section{Introduction}

The study of physiological regulatory mechanisms under huge loads is based on the search for completely new approaches to the prevention and treatment of their multiple consequences. Close interrelation of the environment and body is provided by the activity of complex systems based on different principles, including the famous principle of homeostasis (from Greek homoios similar, stasis - state). If certain elements of these systems are violated, systemic disturbances occur, resulting in the consequences of various severity. The most frequent systemic disorders are connected with adaptation and manifested at various levels of human functioning (from dis- adaptation at the morpho-functional level to psychic and social-psychic disadaptation) $[15,17,31]$.

As a result, the stability and effectiveness of homeostasis mechanisms in different conditions require reinforcement, which can be obtained with the help of oral intake of various biologically active additives (BAA). One of the most famous examples of such BAAs is adaptogens of plant origin. It is traditionally considered that BAAs of plant origin possess a well-established pharmacological effect, which is mostly based on antioxidant activity $[2,3,6]$.

Nowadays one of the main tasks of food sciences and biotechnology is the extraction of new natural ingredients with a targeted biological 


\section{Спортивное питание}

activity, study of their physical and chemical properties and physiological effects as well as their ability to incorporate into the food matrix, maximally preserving biological activity.

Effects of ration on physiological processes of the body are thoroughly studied. This provides great opportunities to improve and maintain health with the help of food products and their ingredients (macro- and micronutrients) $[1,4,6]$.

Such effects should be defined for several reasons.

Firstly, such an effect should be studied both at the initial (oral intake) stage and during intestinal passage.

Secondly, such an effect should be studied with regard to the interrelation of food ingredients with multifactor physiological systems of the gastrointestinal tract and, in particular, with exosecretory enzyme systems of cells, tissues and organs of different parts of the gastrointestinal tract as well as endo- and exoenzyme systems of microbiota. At the same time, in medicine, digestion (the movement of a bolus in the gastrointestinal tract, the changes occurring in it under the influence of digestive enzymes, the absorption of macro- and micronutrients, etc.) is studied and described quite thoroughly (especially in physiology and pathophysiology of digestion) $[15,17$, 31]. However, there is a deficiency of the studies on a current situation, which is characterized by the revolution in food biotechnologies and attempts to create completely new food products based on replacing natural components with genetically modified, trans-isomer or artificially synthesized analogues.

Thirdly, the inclusion into a food matrix of the BAAs of adapter activity is a difficult task in terms of the provision of their bioavailability. The study of information on the improvement of bioavailability allows us to reveal the necessity to develop and select the effective methods for preserving all characteristics of BAAs before achieving physiological action.

Thus, a new direction is being formed in the creation of food products with the plant adaptogens of targeted action that can fully implement stated functional effects, including the regulation of physiological homeostatic mechanisms, to provide body adaptation to changing environmental conditions and increasing loads. In recent years, particular attention has been paid to athletes, especially professional ones. Medical and biological supervision of athletes for the prevention of disadaptive disturbances and adjustment to huge physical loads has become possible due to the inclusion of BAAs with a targeted biological activity in their ration.

Aim. Regulatory functions of the body provide neutralization, binding and excretion of $\mathrm{H}^{+}$ and $\mathrm{OH}-$ ions as a part of various chemical compounds, depending on peculiarities of metabolism and state of buffer systems. Negative influence of the high concentrations of reactive oxygen species (ROS) on cell structures, resulting in DNA, proteins and lipids damage, has been studied quiet well. However, there is also a positive influence of ROS on the cell and its systems [11]. Currently the number of works devoted to the bioregulatory role of pro- and antioxidants in a body reaction to various mediators and environmental factors is increasing [22]. The maintenance of $\mathrm{pH}$ balance at a reference level is very significant for the body. This ratio influences metabolism, including oxidative phosphorylation, proteosynthesis and proteolysis, formation and decomposition of carbohydrates and lipids as the enzyme activity is optimal only for a certain ratio of $\mathrm{H}+$ and $\mathrm{OH}-$ ions.

Nowadays human microbiome is considered as an important antigen reservoir, contacting directly with the immune system on all epithelial structures and playing an important role in the maintenance of homeostasis and health [33]. Another important emerging trend in the study of microbiome is its study together with a diet and pro- and prebiotic factors [20].

Natural adaptogens, which are mostly produced as extracts or drinks, can be used as regulators of the buffer system. Phenolic compounds have special place among biologically active secondary metabolites responsible for an increase in the ability to protect cells under negative environmental factors $[27,30]$. These compounds are characterized by various biological activity and widely recognized due to their ability to minimize risks for a cellular damage provoked by oxidative stress. Phenolic acids can account for about one-third of all phenolic compounds in human diet, while they have a high level of antioxidant activity [28].

Therefore, the development of the adaptogenic drink based on the polyphenol complex of antioxidant activity and optimized in terms of bioavailability is considered as relevant and being the main goal of our study.

\section{Materials and methods}

As a polyphenol complex of antioxidant activity we used the plant extracts obtained in 
the research laboratory of the department of Food and Biotechnologies in the South Ural State University.

1) Extract of the Dahurian larch (Larix gmelinii) with a mass fraction of taxifolin of no less than $97.0 \%$ in the form of cream-white microcrystalline powder was produced in accordance with GOST 33504-2015 "Food additives. Taxifolin. Technical specification". Taxifolin is recommended to be added in soft drinks, yogurts and chocolate pastries (State registration certificate № RU 77.99.11.003.E.018404.05.11 dd. 06.05.2011).

Taxifolin belonging to the $6^{\text {th }}$ grade of safety means that it is non-toxic. The European Food Safety Authority (EFSA) published a final statement on the safety of taxifolin as a new food ingredient. Animal studies revealed that the oral intake of taxifolin in the dose of up to $10 \mathrm{~g}$ per $\mathrm{kg}$ of a live weight did not provoke any disturbances of the body functional state.

Taxifolin is a flavanol, the antioxidant activity of which significantly exceeds many flavonoid compounds due to a specific structure (Fig. 1). The analysis of literature reveals that taxifolin possesses a wide range of biological and pharmacological effects.<smiles>O=C1c2c(O)cc(O)cc2O[C@H](c2ccc(O)c(O)c2)[C@@H]1O</smiles>

Fig. 1. Taxifolin chemical structure

Due to its unique antioxidant activity taxifolin plays an important role in the maintenance of the circulation system, elimination of excessive free radicals, improvement of immune function, reduction of cancer cells and prevention of cardiovascular diseases [2, 6, 8, 13, 14, 28, 29].

2) Betacyanin water extract from table beet (Beta vulgaris L. ssp.vulgaris) with a mass fraction of betanin of $1.5 \pm 0.3 \mathrm{~g} / 100 \mathrm{~g}$ [3]. Red and purple pigments of table beet are the result of a resonance structure between positive indole nitrogen atoms, 3-valent nitrogen of pyridine ring and the system of conjugated bonds (Fig. 2).

Betacyanin resistance depends on corresponding enzymes. It was established that red table beet contains a range of enzymes, in particular, $\beta$-glycosidase, peroxidase and polyphenol oxidase [4]. Betanins are mono- and diglucoside phenol compounds. Under hydrolysis they split into carbohydrates (galactose, glucose, etc.) and aglycones presented by anthocyanidins (cyanidin, etc.). Betanin possesses high antiradiation and anticancer activity. Taxifolin is absorbed from the intestinal tract and acts like an antioxidant, protecting body cells $[4,12,23]$.<smiles>O=C(O)C1=C/C(=C/C=[N+]2c3cc(O)c(O[C@@H]4O[C@H](CO)[C@@H](O)[C@H](O)[C@H]4O)cc3C[C@H]2C(=O)[O-])C[C@@H](C(=O)O)N1</smiles>

Fig. 2. Betanin chemical structure

3) Honeysuckle water extract (Lonicera caerulea $\mathbf{L}$.) with a mass fraction of phenol substances in terms of chlorogenic acid of $0.318 \pm$ $0.02 \%$. Honeysuckle is not only a source of biologically active substances but also an effective treatment for the prevention and cure of various diseases as well as for the recovery of body functions under different disturbances. The main substances, which determine the abovementioned properties, are Epigallocatechin-3-gallate (EGCG), Apigenin (4',5,7-trihydroxyflavone) and Luteolin 2-(3,4-Dihydroxyphenyl)- 5,7-dihydroxy-4-chromenone (Fig. 3).

It was established that each of these biologically active substances can be used as an overthe-counter drug and adaptogene for cancer prevention, elimination of problems connected with oxidative stress and recovery after a huge psychological or physiological load [2, 27].

Dry plant extracts Lonicera caerulea L. and Beta vulgaris L. ssp.vulgaris were obtained using the methods described in the previous articles of the authors [3].

Taxifolin formulation consisted of several preparatory operations due to low solubility and bioavailability of the substance.

Low solubility (approximately $20 \mathrm{mg} / 1$ in water at environmental temperature) results 
<smiles>O=C(O[C@H]1Cc2c(O)cc(O)cc2O[C@H]1c1cc(O)c(O)c(O)c1)c1cc(O)c(O)c(O)c1</smiles>

1 - EGCG<smiles>O=c1cc(-c2ccc(O)cc2)oc2cc(O)cc(O)c12</smiles>

2 - Apigenin

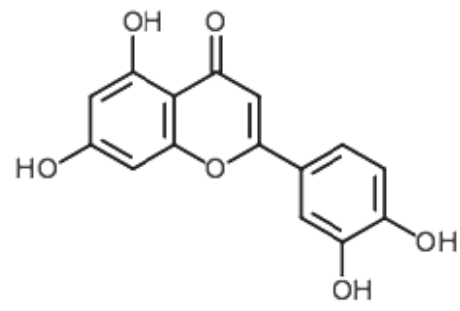

3 - Luteolin

Fig. 3. BAS Lonicera caerulea $L$ chemical structure

in a limited and slow taxifolin absorption, restricting its bioavailability. Moreover, taxifolin, as well as the majority of flavonoids, is chemically and thermally labile, it degradates quickly under the influence of alkaline conditions and high temperature $[8,13,16,21]$.

An increase in taxifolin solubility associates with the specific area of material surface, necessity for particle size reduction and enlargement of effective surface, contacting with the environment [26]. Therefore, to improve taxifolin solubility and bioavailability, it is important to receive small homogenous amorphous nanoparticles $[7,16,26,32]$. We used ultrasound treatment, which allowed us to provide conditions for taxifolin nanostructuring.

1. Taxifolin sample solutions were obtained using the following technology:

Sample 1 (control) - taxifolin weighed amount $(0,1 \pm 0,001 \mathrm{~g})$ is dissolved in $100 \mathrm{ml}$ of distilled water and blended in a laboratory shaker for 30 minutes;

Sample 2 - taxifolin weighed amount $(0,1 \pm$ $\pm 0,001 \mathrm{~g}$ ) is dissolved in $100 \mathrm{ml}$ of distilled water and blended in a magnetic mixer at a temperature of no more than $55^{\circ} \mathrm{C}$ for 30 minutes;

Sample 3 - taxifolin weighed amount $(0,1 \pm$ $\pm 0,001 \mathrm{~g}$ ) is dissolved in $100 \mathrm{ml}$ of distilled water and exposed to 20-minute ultrasound treatment using VOLNA-L ultrasound equipment (УЗТА-0,63/22-ОЛ, Biysk, Russia) at a frequency of $20 \pm 2 \mathrm{kHz}$, radiation intensity up to $100 \mathrm{~W} / \mathrm{cm}^{2}$, power of $630 \mathrm{Wt}$, temperature of no more than $55^{\circ} \mathrm{C}$.

To detect taxifolin particle size we used Nanotrac Ultra (Microtrac Inc., USA) analyzer. Measurements conducted with Nanotrac correspond with ISO 13321 standard.

We used a microscope to study taxifolin particles morphological characteristics and non- colored specimens of a hanging drop type. The study was conducted with the help of $\times 1500$ ALTAMI 136T microscope and a bright-field transmission method. Microscope fields were fixed using 13 ЦК digital camera for the microscope with USB 2.0 interface.

We also used a coulometer Expert-006-antioxidant (State register № СИ РФ № 23192) to detect antioxidant activity in terms of ascorbic acid.

2. Adaptogenic drink sample was obtained using a mechanical mixing of the plant extract with treated water and sugar according to the receipt developed.

The plant extract is reconstituted plant extracts of Beta vulgaris L. ssp.vulgaris and Lonicera caerulea $L$. in the ratio $3: 1$ with a taxifolin mass fraction of $0.1 \%$ and a mass fraction of dry substances of no less than $15 \%$. Taxifolin content in a final product is no less than $0.02 \%$.

The drink obtained was estimated using the following criteria: organoleptic properties, mass fraction of dry substances, main groups of antioxidant substances, general antioxidant activity of the drink.

To establish the consumer's attitude towards the quality of a sample drink, we performed its assessment using descriptive and profile analysis. This analysis as well as QDA-method were developed in 70-s by the company Tragon (USA) and are still among the most popular methods of the sensory analysis, which allows creating products with desired properties $[1,5]$. The content of dry substances was established with the help of the refractometric analysis; betalain content was registered by means of the spectrophotography; antioxidant activity was assessed using the coulometry and Expert-006-antioxidant equipment; total content of phenol substances was established with the help of the spectrography using the Folin-Ciocalteu reagent. 


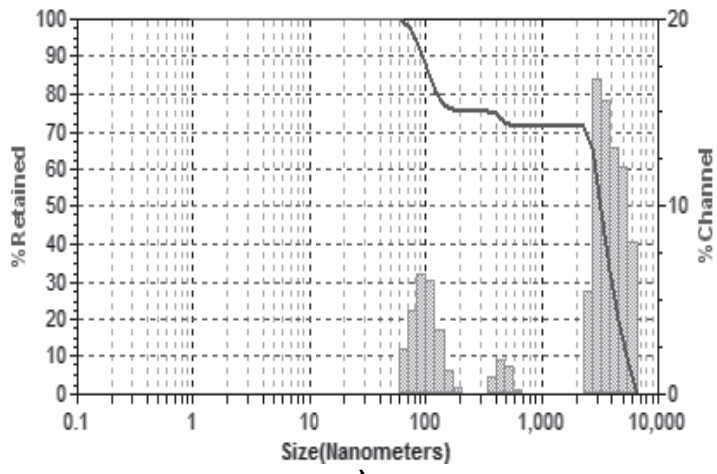

a)

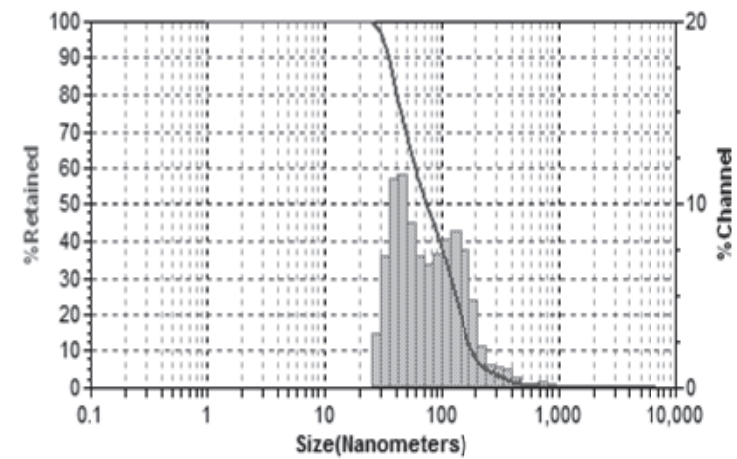

b)

Fig. 4. Distribution curves for the particles of taxifolin water solution: $a-$ control, $b-0.1 \%$ taxifolin solution treated for 20 minutes with $630 \mathrm{~W}$ ultrasound

To estimate the effect of drinks on homeostatic regulation, we formed groups of students on voluntary basis. They participated in the study having declared voluntary informed consent and the absence of intolerance to the ingredients used in the drink.

We estimated the microbial composition of salivary secretion, $\mathrm{pH}$ and enzyme activity of carbohydrate metabolism using traditional methods of analysis.

Saliva sampling was performed without saliva stimulation on an empty stomach in dry testtubes after rinsing with water and after drink intake.

Experimental data were processed using the methods of mathematical statistics and Microsoft Excel program tools.

\section{Results and discussion}

1. Study of taxifolin sample solutions

Analyzing the disperse content we studied ultrasound as an instrument providing ultrathin dispersion, which allows decreasing significantly the interphase interaction of response elements. As it was mentioned, taxifolin solubility is connected with the specific surface of material and can be achieved due to the decrease of particle size [26]. In the scope of our research we worked on the creation of a balanced nano disperse system of taxifolin water solution to provide a better bioavailability of biologically active component.

The dispersive effect of ultrasound is based on the excessive pressure formed by the ultrasonic wave. This pressure combines with a constant hydrostatic pressure that results in a synergetic effect, which equals several atmospheres. In the rarefaction phase, cavities appear throughout the liquid, especially near the phase boundaries, where there are the smallest solid particles and gas bubbles $[9,10,19]$.
All distribution curves obtained for the particles of taxifolin sample solutions had a similar character (Fig. 4), but varied in terms of the magnitude and location of peaks corresponding to particles of different dimensions.

The results obtained revealed that taxifolin water solution is quite sensitive to ultrasonic cavitation. In the control sample (without ultrasonic treatment), there were the particles of $1000 \mathrm{~nm}$ and more with the predominance of the particles of $2838 \pm 52 \mathrm{~nm}$. After 20-minute exposure to $630 \mathrm{~W}$ ultrasound disperse content changed. There were particles of three types: less than $100 \mathrm{~nm}$, $100-500 \mathrm{~nm}, 500-1000 \mathrm{~nm}$ with the predominance of the particles of $337 \pm 24 \mathrm{~nm}$.

It should be taken into account that ultrasonic treatment can result not only in particle destruction, but also in particle coagulation, which is connected with the destruction of the solvate shell of particles in a disperse phase [9, 10]. Therefore, visualization of taxifolin particles allows determining the effect of ultrasound on particle destruction and describing their morphological characteristics.

Taxifolin molecules are polymers, separate links of which are rigidly bonded by hydroxyl groups. A decrease in polymerization results in the increase of the activity of substance, its solubility, ability to enter into chemical reaction and other properties. The structure changes under ultrasonic treatment (Fig. 5).

The microscopic examination of a nontreated taxifolin, mechanically treated taxifolin and the taxifolin exposed to ultrasonic treatment is described in Fig. 5. In Fig. 5a taxifolin granules are presented like ordinary crystalline blocks of different size with a clearly visible shape. The morphology of granules is a fibrous non-homogenous plate-like structure of a crystalline type (Fig. 5b). 


\section{Спортивное питание}

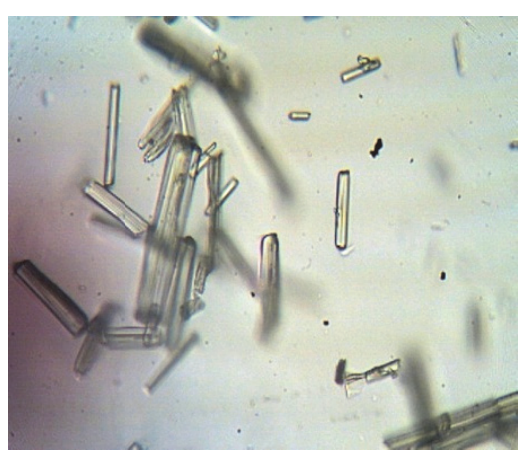

a)

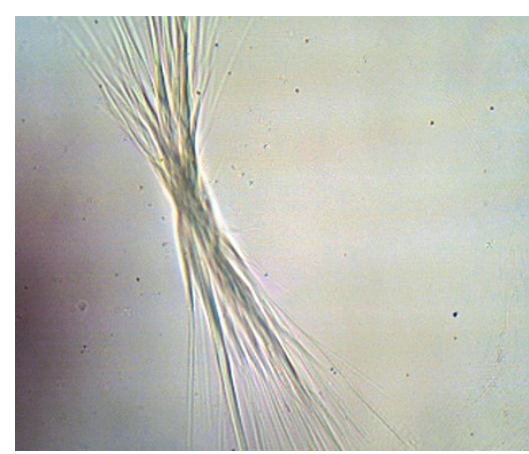

b)

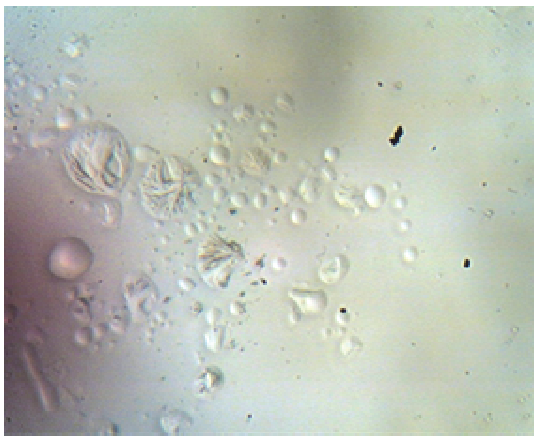

c)

Fig. 5. Microphotographs of taxifolin hanging drop technique samples ( $\times 1500)$ : a $-0.1 \%$ taxifolin (control), b - mechanically treated $0.1 \%$ taxifolin; c - $0.1 \%$ taxifolin exposed to 20 -minute ultrasonic treatment of $630 \mathrm{~W}$

Total antioxidant activity of taxifolin water solutions (coulometric method, ascorbic acid $\mathrm{mg} / \mathrm{ml}$ )

Table 1

\begin{tabular}{|l|c|c|c|}
\hline \multirow{2}{*}{ Name } & \multicolumn{3}{|c|}{$0.1 \%$ taxifolin solution } \\
\cline { 2 - 4 } & Sample 1 & Sample 2 & Sample 3 \\
\hline $\begin{array}{l}\text { Antioxidant activity; } \\
\text { ascorbic acid, mg/ solution, } \mathrm{ml}\end{array}$ & $3.84 \pm 0.08$ & $4.36 \pm 0.14$ & $7.61 \pm 0.12$ \\
\hline
\end{tabular}

The morphological structure of the taxifolin treated with ultrasound (Fig. $5 \mathrm{c}$ ) was close to a spherical shape, while its particles were characterized by amorphous structure, which is positive for taxifolin solubility and bioavailability [16, 29]. Taxifolin bioavailability increases due to a rigid monomeric structure.

During the next stage we assessed the antioxidant activity of sample solutions. Taxifolin proves its effectiveness at a level of cell membranes even at the lowest concentrations. To improve the effectiveness and migration ability of the substance it is necessary that the size of its particles correspond to the size of cells.

The results obtained (Table 1) correspond to the results of the disperse analysis and prove that the ultrasonic treatment of taxifolin solution improves its antioxidant activity.

Antioxidant activity of the $0.1 \%$ taxifolin solution obtained using ultrasonic treatment 1.74-1.98 times exceeds the same parameter for the solutions obtained on the basis of the mechanical approach, that proves the increased physiological value of ultrasonic taxifolin solution.
The results obtained were the reason to choose ultrasonic taxifolin solution as a model for an adaptogenic drink.

2. Study of a model adaptogenic drink based on plant extracts

When creating functional drinks, it is necessary to take into account their attractiveness for consumers. Therefore, we conducted the organoleptic analysis of a drink and received its sensory profile. The drink based on beet and honeysuckle extracts with taxifolin was characterized by intense fragrance and balanced sweet-and-sour taste. Taxifolin introduction had no negative effects on the organoleptic characteristics of the drink.

The study of physical and chemical drink properties is presented in Table 2.

The study of honeysuckle pharmacological activity reveals its antibacterial, antioxidant, antiinflammatory and cancer preventive effects. Biologically active substances of beet are presented by betalains, namely betanin and betaxanthine. These are highly active red and yellow pigments with antihypertensive, antitumor, hypoglycemic

Physical and chemical properties of a model adaptogenic drink

Table 2

\begin{tabular}{|l|c|c|c|}
\hline \multicolumn{1}{|c|}{ Parameter } & Value & Parameter & Value \\
\hline Dry substance content, \% & $6.40 \pm 0.03$ & $\begin{array}{c}\text { Total content of phenolic } \\
\text { substances, mg of gallic acid }\end{array}$ & $194 \pm 4$ \\
\hline $\begin{array}{l}\text { Betanin and betaxanthine total content, } \\
\text { mg/100 g dry substance }\end{array}$ & $54 \pm 2$ & $\begin{array}{c}\text { Antioxidant activity, mg } \\
\text { of ascorbic acid }\end{array}$ & $12.64 \pm 0.02$ \\
\hline
\end{tabular}


and chemopreventive activity [3, 4]. The presence of plant raw in the drink demonstrates its potential for maintaining or improving health, providing stability and effective mechanisms of homeostasis under various conditions.

The analysis of the antioxidant activity of a beet and honeysuckle drink with taxifolin in comparison with the results of previous studies demonstrates the synergetic effect of plant raw biologically active substances and taxifolin.

\section{We performed a complex assessment} of adaptogenic drink effect on homeostatic regulation involving microbiota

As a result of the study it was established that the taxifolin drink based on beet and honeysuckle extracts contributes to a change in salivary $\mathrm{pH}$. After drink intake there was a shift in $\mathrm{pH}$ values within the range from 6.5 to 7.5 in comparison with the initial $\mathrm{pH}$ of $5.5 \div 6.0$. The increase in the acidity of salivary secretion contributes to the development of microorganisms as an ideal $\mathrm{pH}$ level is more than 7.0 (reference values are from 5.6 to 7.6$)[15,17,18]$.

Saliva contains digestive enzymes: $\alpha$-amylase and maltase, as well as non-digestive enzymes: kallikrein and lysozyme. Amylase is the main enzyme splitting starch into trisaccharides, which account for more than $15 \%$ of all saliva proteins. For a maximum effect of $\alpha$-amylase $\mathrm{pH}$ level should be equal $6.6 \div 6.8$. Amylase activity of saliva or amyloclastic force is expressed by the amount of $0.1 \%$ starch solution in $\mathrm{ml}$, which can be split in $1 \mathrm{ml}$ of saliva under the temperature of $38^{\circ} \mathrm{C}$ for 30 minutes. Under normal conditions saliva amylase activity equals 160 ...320 units.

Salivary amylase, as well as pancreatic amylase, splits a-1.4-glycoside bonds in the molecules of starch and glycogen with the formation of dextrin and a small quantity of maltose. Chloride ions activate salivary amylase, while polyphenols act as an inhibitor for enzyme activity. Under the intake of a taxifolin drink there is a decrease in $\alpha$-amylase activity by $120 \ldots 180$ units, it means that the improvement of homeostatic mechanisms can be achieved due to the oral intake of adaptogenic plant complexes.

Saliva performs protective functions. In the oral cavity there are microorganisms, which are not dangerous under normal conditions; constant microflora serve as an improvised biological barrier, as these microorganisms stop the growth of pathogenic microbes. According to different authors, the quantity of bacteria in the oral cavity varies from 43 millions to 5.5 billions, while
Pod Streptococcus

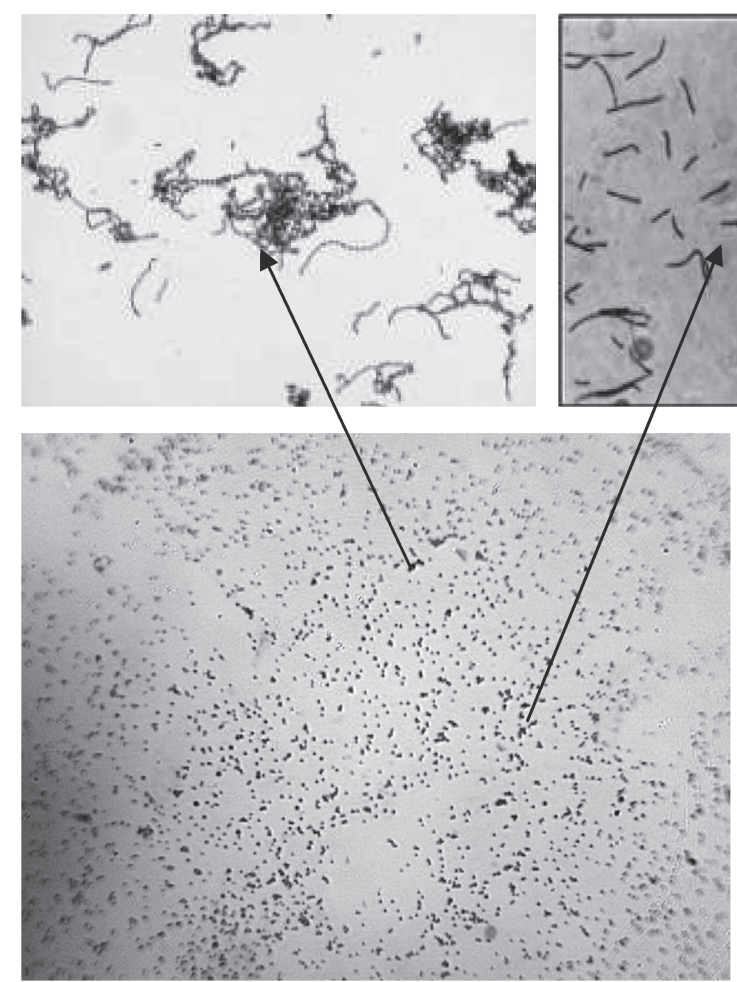

a)
Pod Actinomycetaceae

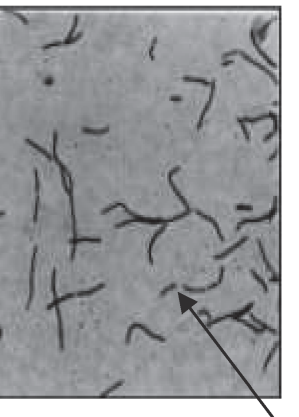

Pod Lactobacillus

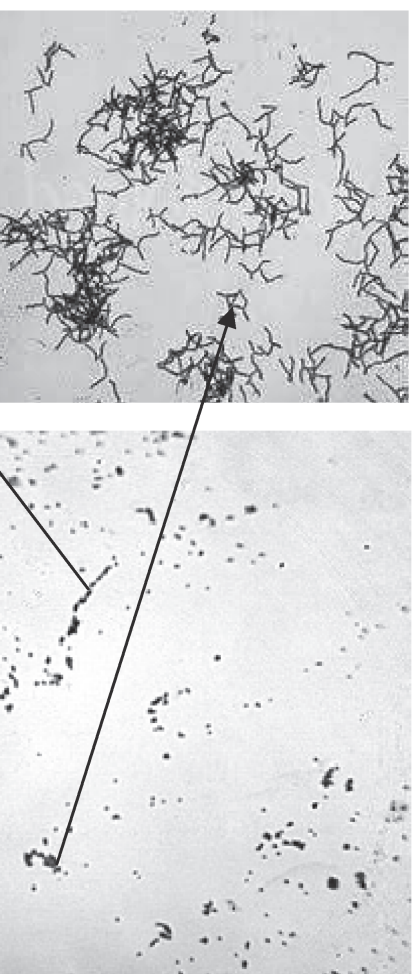

b)

Fig. 6. Microphotographs of the fixed specimens (Gram stain, $\times 1500$ ) of salivary microflora before (a) and after (b) the intake of the adaptogenic drink 


\section{Спортивное питание}

the number of the different types of microorganisms varies from 100 to $160[15,17,25,31]$.

In the samples made of different saliva specimens (Fig. 6) there were different microbes in terms of Gram stain and morphology - streptococcus, tetracoccus, rods and curved forms. The intake of a taxifolin drink provides changes in the level of streptococcus to a statistically significant lower level.

Coccus in the oral cavity are mostly presented by streptococcus (Streptococcus salivarius, S. sanguis, S. mutans, S. milleri, S. mitis) being a group of opportunistic and nonpathogenic coccus, which split different carbohydrates with the formation of lactic acid and other organic acids.

Rod-shaped Gram-positive and Gram-negative bacteria are mostly presented by Lactobacillus, Bacteroides, Prevotella, Porphyromonas, Fusobacterium.

Lactobacteria (L. acidophilus, L. brevis, L. fermentum) participate in the provision of colonization resistance and influence various pathogenic microorganisms.

According to scientists, the ratio of the certain types of bacteria in saliva can become an indicator in the diagnostics of the diseases provoked by homeostasis disturbances and dysfunctional gastrointestinal upsets [24].

\section{Conclusion}

Obtaining a water-soluble taxifolin complex with a high pharmacological activity and development of the better ways of its dissolution still remain relevant. Such plant extracts as Lonicera caerulea L., Beta vulgaris L. ssp.vulgaris and taxifolin are quite promising for the creation of a functional food based on the combination of secondary metabolites (polyphenols). The synergetic effect of taxifolin, EGCG, Apigenin (4',5,7trihydroxyflavone) and Luteolin 2-(3,4-Dihydroxyphenyl)-5,7-dihydroxy-4-chromenone with betacyanin provides the regulatory functions of homeostasis involving microbiota.

The work was supported by Act 211 Government of the Russian Federation, Contract № 02.A03.21.0011 and by State Assignments № 40.8095.2017/БЧ (2017123-ГЗ) and № 19.8259.2017/БЧ.

\section{References}

1. Zavorokhina N.V., Solov'yeva M.P., Chugunova O.V., Pastushkova E.V., Fozilova V.V. [Vegetable Raw Materials of the Urals Region for the Production of Soft Drinks]. Pivo $i$ napitki [Beer and Drinks], 2013, no. 4, pp. 28-31. (in Russ.)
2. Korul'kin D.Yu., Abilov Zh.A., Muzychkina R.A., Tolstikov G.A. Prirodnyye flavonoidy [Natural Flavonoids]. Novosibirsk, Theo Publ., 2007. 232 p.

3. Kalinina I.V., Potoroko I.Yu., Fatkullin R.I. [Results of the Effect of Ultrasonic Cavitation Effects on the Degree of Extraction of Biologically Active Substances From Plant Material]. Agrarnyy vestnik Urala [Agricultural Agrarian of the Urals], 2017, no. 10 (164), pp. 30-35. (in Russ.)

4. Cherno N.K., Lomaka E.V. [Stabilization of Betanine by Complexation with Arabinogalactan]. Izvestiya vuzov. Pishchevaya tekhnologiya [Izvestiya Vuzov. Food technology], 2013, no. 4, pp. 32-35. (in Russ.)

5. Chugunova O.V., Zavorokhina N.V. Ispol'zovaniye metodov degustatsionnogo analiza pri modelirovanii retseptur pishchevykh produktov s zadannymi potrebitel'skimi svoystvami: monografiya [Use of Methods of Tasting Analysis in the Modeling of Food Formulas with Specified Consumer Properties. Monograph]. Ekaterinburg, Urals State University of Economics Publ., 2010. 148 p.

6. Shatilov A.V., Bogdanova O.G., Korobov A.V. [The Role of Antioxidants in the Body in Normal and Pathological Conditions]. Veterinarnaya patologiya [Veterinary Pathology], 2007, no. 2, pp. 207-211. (in Russ.)

7. Abad-Garcia B., Garmon-Lobato S., Berrueta L.A. Afragmentation Study of Dihydroquercetin Using Triple Quadrupole Mass Spectrometry and Its Application for Identification of Dihydroflavonols in Citrus Juices. Rapid Commun. Mass Spectrom., 2009, vol. 23, pp. 2785-2792. DOI: $10.1002 / \mathrm{rcm} .4182$

8. Rogovskii V.S., Matiushin A.I., Shimanovskii N.L. et al. Antiproliferative and Antioxidant Activity of New Dihydroquercetin Derivatives. Eksp. Klin. Farmakol., 2010, vol. 73, pp. 39-42.

9. Fatkullin R., Popova N., Kalinina I. et al. Application of Ultrasonic Waves for the Improvement of Particle Dispersion in Drinks. Agronomy Research., 2017, vol. 15, pp. 1295-1303.

10. Krasulya O., Shestakov S., Bogush V. et al. Applications of Sonochemistry in Russian Food Processing Industry. Ultrasonics Sonochemistry, 2014, vol. 21, pp. 2112-2116. DOI: 10.1016/j.ultsonch.2014.03.015

11. Beckman K.B., Ames B.N. Endogenous Oxidative Damage of mtDNA. Mutation Research. Fundamental and Molecular Mechanisms 
of Mutagenesis, 1999, vol. 424, pp. 51-58. DOI: 10.1016/S0027-5107(99)00007-X

12. Czarniecka-Skubina E. Effect of Culinary Process on Beet Roots Quality. Electronic Journal of Polish Agricultural Universities, 2003, vol. 6.

13. Liang L., Gao C., Luo M. et al. Dihydroquercetin (DHQ) Induced HO-1 and NQO1 Expression Against Oxidative Stress Through the Nrf2-Dependent Antioxidant Pathway. J. Agric. Food Chem., 2013, vol. 61, pp. 2755-2761. DOI: 10.1021/jf304768p

14. Teselkin Y.O., Babenkova I., Kolhir V. et al. Dihydroquercetin as a Means of Antioxidative Defence in Rats with Tetrachloromethane Hepatitis. Phytother. Res., 2000, vol. 14, pp. 160-162. DOI: $\quad 10.1002 /($ SICI)1099-1573(200005)14:3< 160::AID-PTR555>3.0.CO;2-Y

15. Hsu Y.J., Chiu C.C., Li Y.P. et al. Effect of Intestinal Microbiota on Exercise Performance in Mice. J Strength Cond Res., 2015, vol. 29, pp. 552-558. DOI: 10.1519/JSC. 0000000000000644

16. $\mathrm{Zu} \mathrm{Y.,} \mathrm{Wu} \mathrm{W.,} \mathrm{Zhao} \mathrm{X.} \mathrm{et} \mathrm{al.} \mathrm{Enhan-}$ cement of Solubility, Antioxidant Ability and Bioavailability of Taxifolin Nanoparticles by Liquid Antisolvent Precipitation Technique. International Journal of Pharmaceutics, 2014, vol. 471, pp. 366-376. DOI: 10.1016/j.ijpharm. 2014.05.049

17. O'Sullivan O., Cronin O., Clarke S.F. et al. Exercise and the Microbiota. Gut Microbes, 2015, vol. 6, pp. 131-136. DOI: 10.1080/19490976.2015.1011875

18. Lambert J.E., Myslicki J.P., Bomhof M.R. et al. Exercise Training Modifies Gut Microbiota in Normal and Diabetic Mice. Appl Physiol Nutr Metab., 2015, vol. 40, pp. 749-752. DOI: 10.1139/apnm-2014-0452

19. Ashokkumar M., Lee J., Zisu B. et al. Hot Topic: Sonication Increases the Heat Stability of Whey Proteins. Journal of Dairy Science, 2009, vol. 92, pp. 5353-5356. DOI: 10.3168/ jds.2009-2561

20. Hyland N., Stanton C. The Gut-Brain Axis. Dietary, Probiotic, and Prebiotic Interventions on the Microbiota. Academic Press., 2016. $508 \mathrm{p}$.

21. Zu S., Yang L., Huang J. et al. Micronization of Taxifolin by Supercritical Antisolvent Process and Evaluation of Radical Scavenging Activity. Int. J. Mol. Sci., 2012, vol. 13, pp. 8869-8881. DOI: 10.3390/ijms13078869
22. Mittler R. Oxidative Stress, Antioxidants and Stress Tolerance. Trends in Plant Science, 2002, vol. 7 (9), pp. 405-410. DOI: 10.1016/S1360-1385(02)02312-9

23. Nemzer B. Betalainic and Nutritional Profiles of Pigment-Enriched Red Beet Root (Beta vulgaris L.) Dried Extracts. Food Chemistry, 2011, vol. 127 , pp. 42-53. DOI: 10.1016/j.foodchem.2010.12.081

24. Oral Microbiota Levels May Indicate Pancreatic Cancer Presented at: 2014 Meeting of the American Society for Microbiology; May 17-20; Boston.

25. Pyne D.B., West N.P., Cox A.J. Cripps Probiotics Supplementation for Athletes Clinical and Physiological Effects. Eur J Sport Sci., 2015, vol. 15, pp. 63-72. DOI: 10.1080/ 17461391.2014.971879

26. Rasenack N., Müller B.W. Preparation of Microcrystals by in Situ Micronization. Powder Technology. 2004, vol. 143-144, pp. 291-296. DOI: $10.1016 /$ j.powtec.2004.04.021

27. Scalbert A., Williamson G. Dietary Intake and Bioavailability of Polyphenols. Journal of Nutrition. 2000, vol. 130 (8), pp. 2073-2085. DOI: $10.1093 / \mathrm{jn} / 130.8 .2073 \mathrm{~S}$

28. Lee C.W., Park N.H., Kim J.W. et al. Study of Skin Anti-Ageing and Anti-Inflammatory Effects of Dihydroquercetin, Natural Triterpenoids, and Their Synthetic Derivatives. Bioorg. Khim., 2012, vol. 38, pp. 374-381.

29. Zhang Z.R., Zaharna A., Wong M. et al. Taxifolin Enhances Andrographolide-Induced Mitotic Arrest and Apoptosis in Human Prostate Cancer Cells via Spindle Assembly Checkpoint Activation. PLoS, 2013, vol. 8, p. 54577.

30. Azmir J., Zaidul I.S.M., Rahman M.M. et al. Techniques for Extraction of Bioactive Compounds From Plant Materials: a Review. Journal of Food Engineering, 2013, vol. 117, pp. 426-436. DOI: $10.1016 /$ j.jfoodeng.2013.01.014

31. Marchesi J.R., Adams D.H., Fava F. et al. The Gut Microbiota and Host Health: a New Clinical Frontier. Gut., 2016, vol. 65, pp. 330-339. DOI: 10.1136/gutjnl-2015-309990

32. Weidmann A.E. Dihydroquercetin: More Than Just an Impurity? Eur. J. Pharmacol., 2012, vol. 684, pp. 19-26. DOI: 10.1016/j.ejphar. 2012.03.035

33. Ley R., Lozupone C.A., Hamady M. et al. Worlds Within Worlds: Evolutionof the Vertebrate Gut Microbiota. Nat. Rev. Microbiol., 2008, vol. 6, pp. 776-788. DOI: $10.1038 /$ nrmicro 1978

Received 7 April 2018 


\title{
РАСТИТЕЛЬНЫЕ АДАПТОГЕНЫ В СОСТАВЕ ПРОДУКТОВ СПЕЦИАЛИЗИРОВАННОГО ПИТАНИЯ КАК ФАКТОР ГОМЕОСТАТИЧЕСКОЙ РЕГУЛЯЦИИ С УЧАСТИЕМ МИКРОБИОТЫ ОРГАНИЗМА
}

\author{
И.Ю. Потороко ${ }^{1}$, М.А. Беребин ${ }^{1}$, И.В. Калинина ${ }^{1}$, \\ Д.Г. Иванова ${ }^{2}$, Й. Киселова-Канева ${ }^{2}$ \\ ${ }^{1}$ Южно-Уральский государственный университет, г. Челябинск, Россия \\ ${ }^{2}$ Медицинский университет, г. Варна, Болгария
}

Цель работы - разработка адаптогенного напитка на основе полифенольного комплекса антиоксидантной активности, оптимизированного по биодоступности. Материалы и методы исследования. Исследование выполнено на основе полифенольного комплекса антиоксидантной активности: дигидрокверцетина (ДГК) (экстракт Дауской лиственницы (Larix gmelinii) с массовой долей ДГК не менее 97,0 \%) и фитоэкстрактов Lonicera caerulea L. и Beta vulgaris L. ssp.vulgaris, полученных в условиях исследовательской лаборатории кафедры «Пищевые и биотехнологии» ФГАОУ ВО «ЮУрГУ» (НИУ). Для повышения растворимости и биодоступности ДГК использовалось ультразвуковое воздействие (УЗВ), позволяющее обеспечить условия наноструктурирования ДГК в режиме $20 \pm 2$ кГц с интенсивностью излучения до $100 \mathrm{Bт} / \mathrm{cm}^{2}$, мощностью воздействия 630 Вт при температуре не более $55^{\circ} \mathrm{C}$, в течение 20 мин. Фитоэкстракт представлял собой восстановленные растительные экстракты Beta vulgaris L. ssp.vulgaris u Lonicera caerulea L. в соотношении 3:1, содержанием ДГК 0,1\% и массовой долей сухих веществ не менее 15 \%. Содержание ДГК в готовом напитке составляло не менее 0,02 \%. Результаты. Установлено, что водный раствор ДГК весьма чувствителен к ультразвуковой кавитации. Морфологическая структура частиц ДГК раствора, обработанного УЗ была приближена к сферической форме, частицы при этом характеризовались аморфной структурой, что положительно сказывается на растворимости и биодоступности. АОА в 1,74-1,98 раза превышает значения этого показателя для растворов, полученных на основе механического подхода, что указывает на повышенную физиологическую ценность. Напиток, полученный на основе свекольножимолостного экстракта с 0,1 \% ДКГ имел общее содержание бетанина и бетксантина, $54 \pm 2$ мг/100 г СВ; общее содержание фенольных веществ - $194 \pm 4$ мг в пересчете на галловую кислоту. Потребление ДГК-ного фитоэкстрактного напитка обусловливает изменение уровня Streptococcus до статистически достоверно более низкого уровня. Наблюдался сдвиг значений $\mathrm{pH}$ в диапазоне от 6,5 до 7,5 ед. при начальном значении $\mathrm{pH} 5,5 \div 6,0$ ед. Заключение. Комбинации вторичных метаболитов (полифенолов) в виде фитоэкстрактов Lonicera caerulea L. u Beta vulgaris L. ssp.vulgaris и ДГК являются перспективными в технологии адаптогенных напитков для подкрепления гомеостатических механизмов с участием микробиоты уже на этапе перорального поступления в организме человека.

Ключевые слова: адаптогены, микробиота, специализированные продукты питания, антиоксидантная активность, биодоступность.

Статья выполнена при поддержке Правительства РФ (Постановление № 211 от 16.03.2013 г.), соглашение № 02.А03.21.0011 и при финансовой поддержке государственных заданий № 40.8095.2017/БЧ (2017123-ГЗ) и № 19.8259.2017/БЧ.

\section{Лuтература}

1. Заворохина, Н.В. Растительное сырье уральского региона для производства безалкогольных напитков / Н.В. Заворохина, М.П. Соловьева, О.В. Чугунова и др. // Пиво и напитки. - 2013. № 4. - C. 28-31.

2. Корулькин, Д.Ю. Природнье флавоноиды / Д.Ю. Корулькин, Ж.А. Абилов, Р.А. Музычкина, Г.А. Толстиков. - Новосибирск: Тео, 2007. - 232 с. 
3. Калинина, И.В. Результаты влияния кавитационных эффектов ультразвука на степень экстракиии биологически активных веществ из растительного сырья / И.В. Калинина, И.Ю. Потороко, Р.И. Фаткуллин и др. // Аграрный вестник Урала. - 2017. - № 10 (164). - С. 30-35.

4. Черно, Н.К. Стабилизация бетанина комплексообразованием с арабиногалактаном / Н.К. Черно, Е.В. Ломака // Известия вузов. Пищеввая технология. - 2013. - № 4. - С. 32-35.

5. Чугунова, О.В. Использование методов дегустационного анализа при моделировании реиептур пищевых продуктов с заданными потребительскими свойствами: моногр. / О.В. Чугунова, Н.В. Заворохина. - Екатеринбург: Изд-во Урал. гос. экон. ун-та, 2010. - 148 с.

6. Шатилов, А.В. Роль антиоксидантов в организме в норме и при патологии / А.В. Шатилов, О.Г. Богданова, А.В. Коробов // Ветеринарная патология. - 2007. - № 2. - С. 207-211.

7. Afragmentation study of dihydroquercetin using triple quadrupole mass spectrometry and its application for identification of dihydroflavonols in citrus juices / B. Abad-Garcia, S. GarmonLobato, L.A. Berrueta et al. // Rapid Commun. Mass Spectrom. - 2009. - Vol. 23. - P. 2785-2792.

8. Antiproliferative and antioxidant activity of new dihydroquercetin derivatives / V.S. Rogovskii, A.I. Matiushin, N.L. Shimanovskii et al. // Eksp. Klin. Farmakol. - 2010. - Vol. 73. - P. 39-42.

9. Application of ultrasonic waves for the improvement of particle dispersion in drinks / R. Fatkullin, N. Popova, I. Kalinina et al. // Agronomy Research. - 2017. - Vol. 15. - P. 1295-1303.

10. Applications of sonochemistry in Russian food processing industry / O. Krasulya, S. Shestakov, V. Bogush et al. // Ultrasonics Sonochemistry. - 2014. - Vol. 21. - P. 2112-2116.

11. Beckman, K.B. Endogenous oxidative damage of mtDNA / K.B. Beckman, B.N. Ames // Mutation Research. Fundamental and Molecular Mechanisms of Mutagenesis. - 1999. - Vol. 424. - P. 51-58.

12. Czarniecka-Skubina, E. Effect of culinary process on beet roots quality / E. CzarnieckaSkubina // Electronic Journal of Polish Agricultural Universities. - 2003. - Vol. 6.

13. Dihydroquercetin (DHQ) induced HO-1 and NQO1 expression against oxidative stress through the Nrf2-dependent antioxidant pathway / L. Liang, C. Gao, M. Luo et al. // J. Agric. Food Chem. - 2013. - Vol. 61. - P. 2755-2761.

14. Dihydroquercetin as a means of antioxidative defence in rats with tetrachloromethane hepatitis / Y.O. Teselkin, I. Babenkova, V. Kolhir et al. // Phytother. Res. - 2000. - Vol. 14. - P. 160-162.

15. Effect of intestinal microbiota on exercise performance in mice / Y.J. Hsu, C.C. Chiu, Y.P. Li et al. // J Strength Cond Res. - 2015. - Vol. 29. - P. 552-558.

16. Enhancement of solubility, antioxidant ability and bioavailability of taxifolin nanoparticles by liquid antisolvent precipitation technique / Y. Zu, W. Wu, X. Zhao et al. // International Journal of Pharmaceutics. - 2014. - Vol. 471. - P. 366-376.

17. Exercise and the microbiota / O. O'Sullivan, O. Cronin, S.F. Clarke et al. // Gut Microbes. 2015. - Vol. 6. - P. 131-136.

18. Exercise training modifies gut microbiota in normal and diabetic mice/J.E. Lambert, J.P. Myslicki, M.R. Bomhof et al. // Appl Physiol Nutr Metab. - 2015. - Vol. 40. - P. 749-752.

19. Hot topic: Sonication increases the heat stability of whey proteins / M. Ashokkumar, J. Lee, B. Zisu et al. // Journal of Dairy Science. -2009. - Vol. 92. - P. 5353-5356.

20. Hyland, N. The Gut-Brain Axis. Dietary, Probiotic, and Prebiotic Interventions on the Microbiota / N. Hyland, C. Stanton // Academic Press, 2016. - P. 508.

21. Micronization of taxifolin by supercritical antisolvent process and evaluation of radical scavenging activity / S. Zu, L. Yang, J. Huang et al. // Int. J. Mol. Sci. - 2012. - Vol. 13. - P. 8869-8881.

22. Mittler, R. Oxidative stress, antioxidants and stress tolerance / R. Mittler // Trends in Plant Science. - 2002. - Vol. 7 (9). - P. 405-410.

23. Nemzer, B. Betalainic and nutritional profiles of pigment-enriched red beet root (Beta vulgaris L.) dried extracts / B. Nemzer // Food Chemistry. - 2011. - Vol. 127. - P. 42-53.

24. Oral microbiota levels may indicate pancreatic cancer Presented at: 2014 Meeting of the American Society for Microbiology; May 17-20; Boston.

25. Pyne, D.B. CrippsProbiotics supplementation for athletes - clinical and physiological effects / D.B. Pyne, N.P. West, A.J. Cox // Eur J Sport Sci. - 2015. - Vol. 15. - P. 63-72.

26. Rasenack, N. Preparation of microcrystals by in situ micronization / H. Steckel, B.W. Müller // Powder Technology. - 2004. - Vol. 143-144. - P. 291-296. 


\section{Спортивное питание}

27. Scalbert, A. Dietary intake and bioavailability of polyphenols / A. Scalbert, G. Williamson // Journal of Nutrition. - 2000. - Vol. 130 (8). - P. 2073-2085.

28. Study of skin anti-ageing and anti-inflammatory effects of dihydroquercetin, natural triterpenoids, and their synthetic derivatives / C.W. Lee, N.H. Park, J.W. Kim et al. // Bioorg. Khim. - 2012. Vol. 38. - P. 374-381.

29. Taxifolin enhances andrographolide-induced mitotic arrest and apoptosis in human prostate cancer cells via spindle assembly checkpoint activation / Z.R. Zhang, A. Zaharna, M. Wong et al. // PLoS. - 2013. - Vol. 8. - P. 54577.

30. Techniques for extraction of bioactive compounds from plant materials: a review / J. Azmir, I.S.M. Zaidul, M.M. Rahman et al. // Journal of Food Engineering. - 2013. - Vol. 117. - P. 426-436.

31. The gut microbiota and host health: a new clinical frontier // J.R. Marchesi, D.H. Adams, F. Fava et al. // Gut. - 2016. - Vol. 65. - P. 330-339.

32. Weidmann, A.E. Dihydroquercetin: more than just an impurity? / A.E. Weidmann // Eur. J. Pharmacol. - 2012. - Vol. 684. - P. 19-26.

33. Worlds within worlds: evolutionof the vertebrate gut microbiota / R. Ley, C.A. Lozupone, M. Hamady et al. // Nat. Rev. Microbiol. - 2008. - Vol. 6. - P. 776-788.

Потороко Ирина Юрьевна, доктор технических наук, профессор, заведующий кафедрой пищевых и биотехнологий, Южно-Уральский государственный университет. 454080, г. Челябинск, проспект Ленина, 76. E-mail: irina_potoroko@mail.ru, ORCID: 0000-0002-3059-8061.

Беребин Михаил Алексеевич, кандидат медицинских наук, заведующий кафедрой клинической психологии, Южно-Уральский государственный университет. 454080, г. Челябинск, проспект Ленина, 76. E-mail: berebinma@susu.ru, ORCID: 0000-0001-7195-8142.

Калинина Ирина Валерьевна, кандидат технических наук, доцент кафедры пищевых и биотехнологий, Южно-Уральский государственный университет. 454080, г. Челябинск, проспект Ленина, 76. E-mail: kalininaiv@susu.ru, ORCID: 0000-0002-6246-9870.

Иванова Диана, доктор биологических наук, профессор отдела биохимии, молекулярной медицины и нутригеномики лаборатории нутригеномики, функциональных продуктов питания и нутрицевтиков, Медицинский университет. 9002, Болгария, г. Варна, ул. Марин Дринов, 55. E-mail: dg_ivanova@yahoo.com, ORCID: 0000-0002-8336-2925.

Киселова-Канева Йоана, кандидат биологических наук $(\mathrm{PhD})$, доцент, начальник отдела биохимии, молекулярной медицины и нутригеномики лаборатории нутригеномики, функциональных продуктов питания и нутрицевтиков, Медицинский университет. 9002, Болгария, г. Варна, ул. Марин Дринов, 55. E-mail: ykisselova@abv.bg, ORCID: 0000-0001-9692-6227.

Поступила в редакцию 7 апреля 2018 г.

\section{ОБРАЗЕЦ ЦИТИРОВАНИЯ}

Plant Adaptogens in Specialized Food Products as a Factor of Homeostatic Regulation Involving Microbiota / I.Yu. Potoroko, M.A. Berebin, I.V. Kalinina et al. // Человек. Спорт. Медицина. - 2018. - Т. 18, № 2. C. $97-108$. DOI: $10.14529 / \mathrm{hsm} 180209$

\section{FOR CITATION}

Potoroko I.Yu., Berebin M.A., Kalinina I.V., Ivanova D.G., Kiselova-Kaneva Y. Plant Adaptogens in Specialized Food Products as a Factor of Homeostatic Regulation Involving Microbiota. Human. Sport. Medicine, 2018, vol. 18, no. 2, pp. 97-108. DOI: 10.14529/hsm180209 